\author{
Ines Crvenkovska Risteska (North Macedonia) \\ Institute of Ethnology and Anthropology \\ Faculty of Natural Sciences and Mathematics \\ Ss. Cyril \& Methodius - Skopje \\ E-mail: inesc.r.2000@gmail.com
}

\title{
TITO RETURNS TO SKOPJE': THE FORGOTTEN MEMORIES OF JOSIP BROZ
}

\begin{abstract}
After the breakup of the Socialist Federative Republic of Yugoslavia, J.B. Tito's self and legacy were by turns remembered and forgotten to a greater or lesser extent, depending on certain actions taken by the political elites. In this text I am trying to examine this issue by using examples of the actions taken by state authorities and the political centers of power, like in this case the relationship towards the artistic portrait of J.B. Tito by D. Kondovski, Tito's message after the 1963 earthquake in Skopje, which was written on the wall of the then-railway station which is now the Skopje Museum, as well as other cultural monuments and institutions that are associated with the memory of J.B. Tito. In the periods after the independence of the Republic of Macedonia, when VMRO-DPMNE was in power, we can see a tendency for removing or concealing the artwork representing J.B. Tito in the museum depots in order to 'expunge' or cleanse the Macedonian collective memory of Tito's legacy. On the other hand, the initiatives that appear on the internet and in the public media in the periods when VMRO-DPMNE is not in power, especially after 2017, strive to restore J.B. Tito's message on the Museum's wall. The architects of the initiatives believe that J.B. Tito's memory will help reestablish the idea of Skopje as a city of solidarity, because in their eyes, "simply put, any healthy society nourishes such concepts."
\end{abstract}

Keywords: Josip Broz Tito, memory, forgetting, Socialist Republic of Macedonia, post-socialist Macedonia.

In this discussion of the memories and the attempts to forget J.B. Tito in post-socialist Skopje and Republic of Macedonia, we will first attempt to

1 The headline of an article in a daily in a period when the letters of J.B. Tito's message were reinstated on the wall of the Skopje Museum when the message was "restored to its original location." Most of the headlines of articles in the printed and electronic media that covered this event interpret the event in the same manner. 
understand the term collective memory, in which forgetting plays an important role. When authors write about collective memory, they are much more interested in what is remembered and less in what is to be forgotten collectively, i.e., what the party in power wishes for the public to forget. In post-socialist Skopje and Republic of Macedonia, depending on the party in power, we see examples of attempts to bring about collective forgetting of Tito, and in other cycles, the Skopje city hall had initiatives and implemented measures in an attempt to refresh the memories of J.B. Tito in Skopje. An example of this is the restoration of Tito's message on the wall of the Skopje Museum in 2018.

The authors write that memories are "common features of everyday life, they represent common societal frameworks of individual memories (Boym 2001: 53, according to Velikonja 2008: 25), which are exclusively designed to become instruments of the government as an 'ideologically connotated and, like any other mental structure, subject of the mechanisms that are used by centers of social power and their struggle for hegemony - selection, hierarchisation, construction and amnesia'." In order to understand the memories as a category that is being created, "the memory is not merely a value-cognitive process (a more or less verbatim portrayal of something external), but it is also loaded with value-related and emotional content on what is worthy of remembering, what should be remembered and what should not or cannot be forgotten" (Pavićević 2009: 94). This is confirmed by the fact that one can exert influence on such processes, which the authors have ascertained on several occasions: whether some memories will be current in a certain period, and others will be forgotten, intentionally or not. Such a view can be expounded with the idea that "memory is nothing more than merely a collection of practices in the previous sense, which represents an infinite and moldable process of collection, processing, storage and use of experiences" (Pavićević 2009: 95). However, remembering and forgetting, which are key aspects of remembrance, "have always been historically influenced by the fleeting expressions and discursive production of memory" (Pavićević 2009: 104). Thusly, even in examples of J.B. Tito as a symbol of the earlier socialist system, in post-socialist Macedonia, the political parties in power have the sway to deal with that issue. Depending on the party they are in, they assume the right to decide on their own accord whether within their discourse they will look at J.B. Tito and the socialism implemented in the Socialist Republic of Macedonia in a positive or negative light. From a position of political power, they impose their political opinion as the only one that has any bearing, and they also assume the right to carve the dominant narrative about the way J.B. Tito and his socialism treated the Macedonians, Macedonia, etc., whilst being supported by a group of historians, archeologists and other professionals from the period. In line with their ideological policies, they also construct the dominant narrative in post-socialist Macedonia, which the society uses as a foundation for constructing the collective relationship towards J.B. Tito and the cultural heritage created in the Socialist Federative Republic of Yugoslavia (SFRJ) regarding "his self and his legacy." Consequently, we can rightly say that "the way we understand memory is informed by the dominant discourse on remembering, and the dominant 
discourse ultimately depends on the actor's ability to impose and define the agenda. Subsequently, it is the regime, rather than its content, that bestows power to remember. By altering the societal practice of remembering, its content is also altered" (Pavićević 2009: 104).

Certain periods in post-socialist Macedonia were dominated by, as Velikonja puts it, the anti-Tito discourse (Velikonja 2008: 17, f. 14). This is especially evident in the periods in which the right-wing, conservative Demochristian party VMRO-DPMNE was in power. In the periods in which the left-wing, more liberal social-democratic party SDSM was in power, this discourse is gradually relativized. Since only two parties exchanged the reins in 20 years, the fact that there was never a third option gave a boost to the two parties to construct the policies they envisioned for "the self and the legacy" of J.B. Tito in cycles: when one of the parties stops being in power, the other party continues its party policy towards J.B. Tito from where it left off the last time it was in power.

\section{The culture of remembering and forgetting}

A lot has been said in the ethnological and anthropological literature on the memories of J.B. Tito in the post-socialist states in the Balkans. In the ethnological and anthropological literature in post-socialist Macedonia, the memories of Tito are obliquely linked to the research of the cultural heritage in terms of monuments and the changes to the holiday calendar. The few texts that on several occasions, parenthetically mention the memories of J.B. Tito in the later, post-socialist period of the Republic of Macedonia are by Mitja Velikonja (cf. Velikonja 2008, Velikonja 2017).

Velikonja rightfully states that the "policies of remembrance" get materialized by means of "the remembrance industry": by erecting monuments, rite facilities, annual holiday cycles, production of souvenirs, production of 'official' historiography, etc., and are thus an indispensable part of the political, commercial and educational projects" (Velikonja 2008: 25). The same goes for the period of socialism, but also post-socialist Macedonia, exemplified by the Museum of the Macedonian Struggle, launched on September 8, 2011, in Skopje. Thus, in this sense, in the socialism period, we can talk about the establishment of the socalled socialist realism concept (Merenik 2009: 128) of the new cultural policy of the SFRJ and its official arts right after World War II, but one may say as early as the second session of $\mathrm{AVNOJ}^{2}$ in 1943. It is established as an exclusive artistic program that encompasses the memories of the anti-fascist struggle that are to be used for shaping the important feature of identity (Cipek 2009: 157). The struggle of the partisans and the 1945 victory lie in the core of the communist perception of history (Cipek 2009: 157), and so does, of course, supreme commander Josip note)

2 Anti-Fascist Council for the National Liberation of Yugoslavia (translator's 
Broz Tito. As a result of the establishment of such a program, aimed at creating 'a unique socialist culture' (Rot 2000: 147), the (cultural) minorities in the ethnographic research were neglected - which in Rot's view also had long-term consequences. This gave birth to the trend of painting his portraits, for which the country allocated a special fund until his death in 1980. The first portrait of Josip Broz, by Mosha Pijade in 1930, marked the beginning of the creation of the political 'icon' of the revolutionary, and later also the socialist leader, who after the second session of AVNOJ was bequeathed the title of marshal of SFRJ. Merenik finds a close link between such artistic production, including portrait paintings, media portraits, photographs and sculpture on the one hand and, on the other, the rhetorical and ideological concept of the body politic for the engulfing and omnipresent communist body embodied in the Leader: all manner of visual representations that mainly contain the idea for a unique and perfect structure of the functioning socialist society, whose visual, emblematic and iconic figure is Josip Broz Tito (Merenik 2009: 131). While Merenik says in her text that the sculpture, as well as the portrait paintings in socialist realism, assume the role of a paradigmatic extension of politics, government, and power (Merenik 2009: 129), Makuljević frames the art related to Tito's portraits in the category of modern artwork that breaks away from the Soviet model after SFRJ got separated from the Soviet Union in 1948. He goes on to say that this is a period when "art is free from the party shackles, and the acceptance of the modernist expression becomes one of the hallmarks of the Yugoslavian artistic practice" (Makuljević 2017: 424). After this period, there is an increase in the number of artistic portraits of J.B. Tito, and some of them served as an example for the other artists in SFRJ. There are a plethora of artists who included portraits of Tito in their artistic corpus, such as Lazar Licenovski and others. The artists could comment more than me on Licenovski's art, who was at the height of Macedonian and then-Yugoslavian art. However, there is a piece of information that is mentioned by other authors, and that must be shared - namely, an important control mechanism in the art of the period were J.B. Tito's personal views of art movements and styles. In that context, "art was censored primarily when Tito's self was criticized" (Makuljević 2017: 425); that is when the portraits violated the provisions of the laws from 1953, 1977, and 1984 which safeguarded J.B. Tito's self. Half a century later, due to J.B. Tito's influence on artistic trends and control of art, he became "the main cathartic medium for the destruction of the symbolic marker of the toppled regime" (Merenik 2009: 129). This vindictive attitude towards socialist heritage started before the breakup but was more pronounced "immediately after the breakup of Yugoslavia and socialism, when communist monuments were dispossessed of their functional sense because they had lost their symbolic sense" (Kuljić 2014: 45). 


\section{Should we remember and/or should we forget Tito?}

In his book "Titostalgia," when Velikonja attempts to clarify the logic behind the discourse for managing the collective memory of Tito in post-socialist Balkan countries, he bases his explanation on the fact that the discourse in that period is in a way a reflection of the ubiquitous discourse in socialist times. The only difference he notices is in the way the new actors apply the discourse to the new political myths, symbols, and rituals, as well as to the new 'authentic jargons,' infinitely reproduced like those in the past (Velikonja 2008: 17). Apart from paying great attention to titostalgia in the independent Balkan countries, he also submits an interesting proposal, namely he suggests an analysis of the 'antiTito' discourse that was developing in tandem with the 'pro' discourse within and outside the territory of SFRJ and later, in the post-socialist states and the Republic of Macedonia. Velikonja detects such 'anti-Tito' discourse in the measures following the transformation of the socialist regime and the breakup of SFRJ, in the measures carried out on the territory of former SFRJ when "a few thousand monuments and symbols of the national liberation movement, socialism, Yugoslavia, its hero leaders, and Broz were removed, destroyed, defaced, stolen or damaged" (Velikonja 2008: 75, footnote 153). Of course, that did not take place with uniform intensity and distribution. It seems that these measures were present to a greater extent in the republics where Tito's influence as a symbol of 'Yugoslavianism' was greater, where he was more present physically, as well. In post-socialist Macedonia, for example, we cannot talk of such measures. We can talk of instances when J.B. Tito's portraits, put up in the public institutions in the era of SFRJ, were removed and the public lost any trace of them, as well as the gradual doing away with the letters and bronze boards containing J.B. Tito's message for Skopje he left after the earthquake on July 27, 1963, which were put up over the remains of the demolished wall on the east facade of the facility /../ in terms of the catastrophic earthquake and the restoration of Skopje (webpage, Skopje Museum, 2019). Thus, the message was removed from the wall of the old Skopje railway station, according to the newspaper articles, on November 9, 2001, upon the request of the then-minister of the culture of the Republic of Macedonia. "The government was elected at the 1998 elections, but there were a number of changes to the structure of the government by 2000 . /.../in the next two years /.../ Ganka Samoilova - Cvetanova, who launched the initiative for removing Tito's message from the old railway station, was in charge of the Ministry of Culture" (skopjeinfo.mk, 18.04.2018). The future museum directors and employees mention that even though the styrofoam letters were removed 17 years ago (if we take 2018 as a reference point), one could make out the message from the traces of the glue used to fasten the letters to the wall. Seven years after the letters were removed in 2000, the bronze boards with the message were completely removed as well, and the explanation was that the hall housing them is due for renovation. In the eyes of the employees, the reason for this move was the clash of ideology between the current government, headed by VMRO- 
DPMNE, and the previous socialist establishment (Telma TV, April 22, 2018). One of the few groups of people that objected this move in that period were the members of the Titovi levi sili ${ }^{3}$ party), who, when the museum services attempted to remove the message, almost sparked an incident. The 'Titoists,' as they were dubbed in the media of that period, were appeased when they got assurances that the message would be returned after the reconstruction of the wall (build.mk web portal, October 5, 2010). On November 8, 2010, the letters conveying Tito's message, which were on the wall of the Skopje Museum were finally removed, and the museum authorities announced that 'the message will return to its place' immediately after the reconstruction (Utrinski vesnik daily, November 8, 2010). Later, in place of the letters that were removed, the museum managers wrote the message on a plaque in a much smaller format that was hung next to the entrance of the Skopje Museum.

On the other hand, ever since the independence in 1991 and a decade later, the memories of J.B. Tito resounded in public discourse; for example, we can mention the initiative of the then-president of the Republic of Macedonia, Branko Crvenkovski (the former president of SDSM), launched on May 8, 2005, to erect a cast bronze statue of Tito on the occasion of the $60^{\text {th }}$ anniversary of the triumph over fascism. The reasoning behind the initiative was that Tito was a leader in the fight against fascism and that he was a historical figure that has contributed to the formation of Macedonian nationality and Macedonian statehood (Gerazova 2006: 98). The president envisaged for the statue to be erected in the center of Skopje. In the periods when VMRO-DPMNE was in power, it was impossible to implement the ideas that aimed at painting a positive picture about J.B. Tito, and in this period, as well, the resistance was in line with the dominant narrative of the party in power, in which J.B. Tito was seen as a villain. This is confirmed with the thesis that "the dominant narratives about the past have a role of an organizing principle of collective memory" (Pavićević 2009: 95), which is a result of the current dominant discourse, which is used as a stepping stone for, among other things, creating the public opinion on the initiative for erecting a statue in the Skopje city center. In order to illustrate the influence of the dominant discourse in percentages, in her essay dedicated to Tito, Gerazova draws on the results from the poll on whether there should be a monument of Tito in Skopje (Becū daily, May 9, 2005, cited according to Gerazova 2006). In Gerazova's essay, we can find no information about the research sample size, but the results show that $39 \%$ of the respondents supported the monument, while $61 \%$ were against the erection of a monument of J.B. Tito in the Skopje city center. Many years later, on November 29, 2013, a monument of J.B. Tito was erected in front of the namesake high school in the Skopje center, adjacent to his bust. According to the media statements of Slobodan Ugrinovski, the president of Titovi levi sili, the statue in front of the J.B. Tito high school was erected by a group of citizens to mark the $70^{\text {th }}$ anniversary of the second session of AVNOJ, ahead of November 29, Republic Day, which was celebrated during SFRJ. The statue is a replica of the famous statue by sculptor Antun Augustincic, which was erected in front of

3 Tito's leftist forces, (translator's note) 
J.B. Tito's family home in Kumrovec, Republic of Croatia. According to some media, the president of the Titovi levi sili party claimed that he has the necessary technical paperwork, without revealing who had issued the building approval, while according to another medium, which supported the current government policies, the municipality of Center did not foresee this sculpture in the detailed urban plan (Nova TV, November 11, 2013). It is important to note that the president of the municipality of Center in that period was a member of the Liberal Party, a coalition partner of SDSM, which was in opposition to VMRO-DPMNE, the ruling party in that period.

According to Tanja Perovic, this volatile, uncertain attitude towards the 'self and the legacy' of J.B. Tito within the territory of the states that were established as a result of the breakup of SFRJ in a 20-year period, has to do with the ethnic and political tension, and we would say that it is related to the way the governing political parties perceive the process of building the national identity of the communities in the independent post-socialist states, including postsocialist Macedonia. Perovic writes that the nostalgia towards J.B. Tito is "less evident in the countries which became independent recently or in places where there is still extreme political tension (Macedonia, Montenegro, and Kosovo)" (Perović 2008: 6,7, according to Velikonja 2008: 39). However, in her view, that does not mean that nostalgia is not present there on an individual basis, because, as she points out, she was able to notice it in the interviews and conversations with her collocutors. So, in this sense, in the discussion in this text, perhaps we cannot talk about excessive nostalgia, but about the memories of J.B. Tito. Even though some people are relentlessly trying to forget them, certain individuals believe that they should remain in the collective memory of the citizens of Skopje. An example of this phenomenon is the initiative of certain individuals on social networks for returning Tito's post-earthquake message and the one for restoring Tito's portraits in the public sphere.

The general conclusion from what we have discussed so far about the public discourse related to J.B. Tito is that it has been contingent on the dominant discourse of the two ruling political parties in Macedonia since 2000. The periods when the Demochristian right-wing VMRO-DPMNE is in power are especially pertinent for the buildup of the anti - Tito discourse in post-socialist Macedonia. 1998-2002 and 2006-2016 are exceptionally significant periods for the buildup of the anti - Tito narrative. That is when, in the dominant discourse on J.B. Tito, he is being explicitly presented as a villain in Macedonian national history, and there are flagrant attempts to 'breakaway' from the cultural heritage related to 'his self and his legacy' created in the socialist period. 


\section{How did Skopje become the city of solidarity?}

The way the population of the Socialist Republic of Macedonia perceived J.B. Tito was informed by the big picture conveyed by the Yugoslavian party industries, and supported by the institutions, media, etc., but also by his 16 visits first to the National Republic of Macedonia, and then to the Socialist Republic of Macedonia, until his demise in 1980. In terms of the significance and the essence of his visits, his initial visits after World War II, on the occasion of the Macedonian uprising and the anniversaries of Macedonian independence, were especially important as they left a very positive impression due to the support he thus gave to the Macedonian people. In regard to how he became important to Skopje and its citizens, his visit after the catastrophic earthquake on July 26, 1963 , is of utmost significance. J.B. Tito visited Skopje 'within 24 hours' of the catastrophic earthquake (portal Macedonium), but also in the first month after the event, together with Nikita Sergeyevich Khrushchev, the president of the Soviet Union.

During his visit to the demolished city of Skopje on July 27, he announced that the Yugoslavian communities and the world would contribute considerable funds for its restoration and reconstruction. He stated: "Skopje faced a major catastrophe, but we will rebuild Skopje with the helping hand of our entire community. It will become a symbol of brotherhood and unity, of Yugoslavian and world solidarity" (J.B. Tito, Skopje, June 27, 1963; portal Macedonium; Okno, 22.07.2013). Thus, in the period after the 1963 earthquake, the Restoration and Reconstruction Fund for Skopje becomes the symbol of Yugoslavian unity and solidarity (Jančeva, Litovski 2017: 163). It was established by the decision of the Federal Assembly in order to rectify the consequences of the catastrophic earthquake that hit Skopje, the capital of the Socialist Republic of Macedonia, at 5:17 a.m. on June 26,1963 . The international humanitarian organizations, as well as the peoples of the Yugoslavian republics, organized a large-scale humanitarian undertaking to offer different kinds of assistance to the city in terms of cleaning up, repairing, and, later on, restoration.

The city was restored in a relatively short period. Skopje acquired the moniker 'City of solidarity.' In order to express gratitude for the support, in April 1975, Tito's message was written in gold-painted styrofoam letters on the demolished part of the eastern façade of the old railway station in Skopje. The railway station was in 1968 converted to a museum, and it housed the Skopje museum (Skopje Museum website, Skopje, 2019). These decisions contributed to the drafting of policies related to the memories of the earthquake, J.B. Tito, and solidarity. Dzvezdan Georgievski, in his article on the old railway station, in his view the most memorable city landmark, reminds us that according to the data available, the first railway station was first to open in 1873 and it served the city for more than six decades. In order to promote railway traffic, the banate management started to build what is known today as the old railway station on the same spot as the first railway station. This station, designed by Serbian architect Velimir Gavrilovic, was launched in 1940. During World War 
II, it was bombarded, and its right flank was struck, the same section that would later collapse in the earthquake. Even though this section was renovated after the war, it was still not as sturdy as the main structure, so it was razed to the ground by the earthquake/.../ It was decided immediately after the earthquake that the demolished part of the station, including the remaining platforms, the few carriages, and of course the clock would be salvaged as a memento of the tragic moment in the history of Skopje. The restoration of the old railway station in the real sense of the word, according to the blueprint and the project of architect Stanislav Petrovic, which was carried out by the Pelagonija construction company, began in 1968 and lasted until 1970. In 1975, Tito's famous statement, which he gave at that very spot, was fastened to the wall next to the ruins (Okno, July 22, 2013).

The message that was secured to the old railway station became symbolic of Skopje as a city of solidarity. Every commemoration of the anniversary of the earthquake and every article dedicated to the events related to the earthquake have begun with this message. But, as the years went by, the situation changed.

\section{How has Josip Broz Tito's memory been petering out for 20 years?}

On the topic of the period after the breakup of SFRJ, Dzeric writes: "As the situation changed - the wilting of the Yugoslavian institutions, the death of its leader and the fall of communism - the strategically and legally imposed forgetting started to compete with the official memory"(2009: 91). In the independent states, the national memory related to the existing alternative memories, which, generally speaking, excluded the previous memories, even those related to 'the self and the legacy' of J.B. Tito and his message for Skopje as a city of Yugoslavian brotherhood, unity and solidarity, gradually started to become institutionalized. In post-socialist Macedonia his message started slowly to fade away, especially after 2000. An activist who follows and comments the events related to the removal of the letters of the message as evidence of the start of the process of forgetting, points out to the statement of the then-director of the Skopje Museum, who on the topic of the removal of the letters from the wall (the panel) of the Museum, mentioned that the wall must be restored, and promised that the letters would be kept in a safe spot. Three years after the letters were removed, the same manager, when asked what the status of the message restoration procedure is, answered with a rhetorical question: "And, what difference does it make today what Tito had said?” (Joci, Virtus Veritas, June 26, 2018). This attitude towards the message points to the formation of an anti-Tito dominant discourse and to the direction in which the organization moved in the Macedonian society in the period to follow. So, in the eleven years following 2006, the forgetting will be directed towards 'a venerated cult of Josip Broz - Tito' (Achkoska 2016: 88), and it was identified as such by a group of historians associated with the party in 
power who wielded great power over the way the discourse developed in that period.

If we take a look at several points in the history of the attitude towards Tito's message, we can find examples of the fact that J.B. Tito started to gradually fade away in public discourse until the message was completely removed. Namely, in that way the essence of the idea of Skopje as a city of solidarity was changed. In the speech given by the VMRO-DPMNE mayor of Skopje, on the occasion of the launch of the exhibition Meeting of Solidarity 1964-1973 in 2011, he says that the focus of the celebration are the clock as a witness of the event, the efforts of the Skopje citizens to undo the damage and the solidarity mission that united the world, whereby Skopje became a city of solidarity (Official portal of Skopje city, July 27, 2011). 'The solidarity meetings' have the primary meaning in the creation of the idea of the city of solidarity: "The Skopje city hall, on May 18, 1964, passed the decision that in the period between July 26 and August 2, on an annual basis, Skopje should host solidarity meetings at which the city friends from around the world would compete in the fields of culture and sports. The idea soon became a reality. The first meeting was held on July 26, 1964. The 'meeting of solidarity' grew into a tradition and a grand international event. Every summer, the city on the Vardar river was the center of solidarity and exceptional human accomplishment, not only on the construction grounds, where the new city was born with the help of international solidarity but also in the fields of culture and sports. Skopje became an open city - a city for all citizens of the world" (Official portal of Skopje city, July 27, 2011). The mayor's message reveals that in the creation of the idea of Skopje as a city of solidarity, the significance of Tito and his message has changed along with that of Yugoslavian solidarity, including material support and all other facets. In his speech, he links the idea of the city of solidarity to international solidarity that must be preserved in the sense of Skopje being an open city for all citizens of the world. As part of the celebration of this day in 2013, we can also notice the practice of including a liturgy for the deceased and a memorial service for the victims of the catastrophic earthquake, held in the Church of Saint Clement of Ohrid (Kanal 5 television, July 26, 2013), thus assigning it religious properties.

Simultaneously, as part of the creation of the anti-Tito and antiYugoslavian position headed by the governing political elites, under the influence of an influential group of historians and other scientific and semi-scientific circles, a societal position towards the SFRJ socialist ideology and social order, as well as its leader and president, J.B. Tito is being defined also by the construction of particular institutions that would be named in this vain. Such is the example of the Museum of Macedonian Struggle. The museum exhibits were designed by a number of different professionals and scientists, among which professor Violeta Achkoska, who is in the spotlight as head of the project. The article on the history of the museum, on the museum's webpage, talks about the educational character of the exhibits, which are mostly wax figures of individuals who present themselves as patriots and victims of communism. The figures are a reminder of their suffering during socialism, and the message is that the Macedonian society 
should free itself from Yugoslavian socialism, which has been imposed: “...The museum exhibits document the suffering endured by Macedonian patriots, who did not concede to a partial solution to the Macedonian issue within communist Yugoslavia, and who fought against the communist government and the imposed 'Yugoslavianism'... (webpage of the Museum of the Macedonian Struggle for Statehood and Independence, history, February 2019). The narratives illustrate, and the wax figures materialize this idea in the Museum of the Macedonian Struggle for Statehood and Independence - Museum of the Internal Macedonian Revolutionary Organization (a.k.a. the VMRO Museum) (until February 2019). Within the focus of our interest, we paid special attention to the exhibition in the Museum of the Victims of the Communist Regime (until February 2019). That was a project of the government of the Republic of Macedonia implemented by the Ministry of Culture of the Republic of Macedonia and established by the decision of the government of the Republic of Macedonia on July 31, 2008. The construction of the museum began in 2008 and lasted for three years. The museum was launched at the $20^{\text {th }}$ anniversary of Macedonian independence, on September $8^{\text {th }}, 2011$ (webpage, Museum of the Macedonian Struggle for Statehood and Independence, history, until February 2019). The 2011 narratives confirm the ongoing process of forgetting, when any procedure against a person who does not meet the 'patriotism' criteria, governed by the concept of the VMRO Museum (until February 2019), is authorized. That would also be confirmed with the opinion of Cipek, who states: “...When something loses its value in the dominant discourse, anybody can revile it” (Cipek 2009: 161).

Upon our most recent visit of the webpage of the Museum of the Macedonian Struggle, in late March 2019, we could see extensive changes to the webpage, which on the other hand is an indicator of yet another reorganization of collective memories in the structure of the now newly named Museum of the Macedonian Struggle. Namely, no the webpage, the segment called Museum of the Victims of the Communist Regime is no longer separate. In the segment of history, the texts explaining the reasons for the establishment of the museum and the way it was established, which were on the website a month earlier, are no longer there. The change in the structure and the narratives on the museum's webpage is testament to the fact that the change of the party in power and the museum's management resulted in a change in the relationship towards the memories of socialism and J.B. Tito, and that another restructuring of collective memories of them, in general, is to follow.

The other example of the process of forgetting J.B. Tito, which begins at the moment the Republic of Macedonia became independent, is the case with the artwork, i.e., Tito's portraits which through the years started to vanish from the public institutions where they were put up in the time of socialist Macedonia. On one occasion, while browsing through social media, we came across an interesting post by I.P., who was interested in the portrait by Dimitar Kondovski, commissioned by the National and University Library on the occasion of the launch of the new building in 1972. His idea was to return the portrait to its original location, since it is in the depot of the Museum of Macedonia, (I.P., 
October 27, 2018, personal FB profile), where according to the collocutors it has been hidden and covered for over 20 years so that nobody can look at it. One of the people in the discussion about the initiative was the head of the Museum of Macedonia, who confirmed that the painting is indeed in the museum depot. Other experts in the field of art history confirmed that this portrait is not the sole example and that most of Tito's portraits from the period of the Socialist Republic of Macedonia have been hidden from the public eye similarly. The aficionados of artistic and architectural pieces from the socialist era mention some more works. For example, there is talk of the painting of Tito that was put up on the wall between the two floors of the NAMA (Naroden magazin) shopping mall, which they assume is by Hegedušić, then Tito's painting by famous author Tomo Shijak, which was in the barracks of the City of Skopje which is now used as a storage room for documents (I.P., October 27, 2018, personal FB profile), and others which are talked about in plural, which leaves the impression of heritage that was forsaken entirely: "I don't remember this portrait of Tito (refers to Kondovski's portrait), but I know that there were portraits of the Marshal by other painters. What's happened to them, where are they, does anybody know? We could turn a blind eye to them if they were in a private collection or somewhere in public, but we no longer see portraits of the Marshal. Their artistic value should not be hidden, or worse, neglected and lost somewhere... Of course, there should be a record of the current location of all the paintings. That goes for Dimitar Kondovski's work, as well, which should not be left to rot in some bunker or, God forbid, end up at a landfill. We will restore it to public space by all means!!” (R.B.N., I.P., October 27, 2018, personal FB profile).

\section{Speaks Skopje ${ }^{4}$ : Solidarity Returns Home ${ }^{5}$}

The initiative in the previous quote from the discussion continues with the various ideas about what should be done about Tito's portraits and message: "The painting must be taken out of the cellars so that it can again see the light of day. According to my modest, non-expert opinion, I believe it belongs to the Skopje Museum, together with all the documents to Tito's message about the 1963 earthquake. Let's restore the painting like we did the letters!" (I.P., October 27, 2018, personal FB profile). This discussion on the personal profile of I.P. with the other participants can be seen as a support of the initiative to return J.B. Tito's letters, which, according to the manager of the Skopje Museum, was submitted to the museum and the Ministry of Culture by a group of citizens. The reasons for the initiative for the restoration of the letters, according to its supporters,

4 A title of a four-day event (July $23-26,2018$ ) organized on the occasion of the $55^{\text {th }}$ anniversary of the catastrophic earthquake in Skopje in 1963 by the mayor of Skopje. The title was used as a headline for most of the articles in the media during that period.

5 A title of a headline in the printed media. 
can be found in the Skopje citizens' collective memory, where “Josip Broz Tito's message that he gave after the earthquake on July 26, 1963, had a prominent spot and was considered a yardstick in existence and the nurturing of human relations in the tragic moments of the life of a city. Spurred by the echo of the message and the fact that it needs to exist for the future generations, we, a group of citizens, are launching an initiative for it to be restored in the location of the old railway, which is today the Skopje Museum" (skopjeinfo.mk, April 18, 2018). The initiative in the internet discussion led by I.P. about Kondovski's portrait does not refer only to this work of art but to the entire cultural heritage of J.B. Tito, which, as we could see, in the text above, is in the risk of being forgotten. Others, including cultural workers, regard the removal from public space solely from the aspect of the technical procedure for protection. In their view, the work has to be sent to the museum depot for storage, so they believe that it is 'not concealed,' but merely deposited for storage. However, there is only one relevant issue for the individuals who believe the cultural heritage related to Tito's 'self and the legacy' is being 'concealed.' Namely, they wonder why the painting was removed from the public space and why instead of being restored after the reconstruction of the facility, it was sent to the museum depots, thereby covering the traces for the public. Thus, an established art historian and a professor at the Cyril and Methodius University - Skopje, points out: "I've been looking for this painting for years!!!! While I was a student, it was hung between the two large reading rooms in the National and University Library. I believe it's their property. /.../I've mentioned it in class countless times..."(I.P., October 27, 2018, personal FB profile). However, according to most of these people, apart from the large portion of the cultural heritage which is part of private collections, there is no trace of most of it, or, like in the case of Kondovski's painting, it 'is concealed' in the Skopje Museum depot. According to the initiative of the people in the discussion, in order for them to be displayed in public, one option would be for "an institution to curate a retrospective exhibition where all the works would be showcased...” (E.P., I.P, October 27, 2018, personal FB profile).

As we could see in the text above, the discussion also takes into account the successful initiative for returning J.B. Tito's message to its old spot, but now within a new concept for the city of Skopje as a city of solidarity, where Tito's message would again find its footing. The people launching the initiative state:

"The original (letters) were made out of styrofoam, and they had patina on the surface due to their age. However, yes, they could have been better. The key thing was to return the message, for it to be a constant reminder of the importance of solidarity" (A.A., I.P., October 27, 2018, personal FB profile)/.../ They should be molded properly, using patinated bronze, to immortalize the message, as it should be" (N.G., I.P., October 27, 2018, personal FB profile).

"That is no ordinary message. It is a promise that a better city shall be born with the aid of solidarity. We did that, i.e., we received that. As a gesture of consideration, of extreme respect towards the moment and the period. And the phenomenon of solidarity in general. Simply put, any healthy society nurtures that concept» (D.P., architect, Telma television, April 22, 2018). 
The letters of Tito's old - new message were designed in a font, which was unacceptable to many. But, the proponents of the internet initiative recommend that the concept of solidarity is something that should be nurtured by any healthy society and that should last forever, as showcased by the idea for returning J.B. Tito's message 'to its old spot' - in the museum and in the memory of the Skopje citizens.

\section{Conclusion}

The message conveyed by J.B. Tito after the catastrophic earthquake on July 26, 1963, was put up on the wall of the old railway station, which today houses the Skopje Museum, and the 1972 portrait of J.B. Tito by Dimitar Kondovski was hung on the front wall between the two reading rooms in the National and University Library in Skopje. After the Republic of Macedonia became independent, the anti-Tito discourse started to pick up momentum in the independent state, which meant activities for removal of the message and the portrait from public spaces. The process of 'breaking away' from the past related to J.B. Tito and his cultural heritage has endured for more than 20 years, but it had its heyday in the periods between 1998 and 2002 and between 2006 and 2017 when the country was governed by the right-wing, Demochristian party of VMRO-DPMNE. In the intermittent periods and after 2017, the process of restoring the memories of J.B. Tito gained impetus. Tito's self and legacy were remembered with the help of many initiatives, but for us, in this text, only two matter. The first one is the initiative on a social network, which we could see on a private profile, and the other launched simultaneously, was by a group of citizens who submitted it to the Skopje Museum in order to restore J.B. Tito's message to 'its old spot,' on its wall. Both initiatives have the same goal, namely, to restore Tito's portrait and his message for Skopje after the earthquake to the collective memory of the citizens of Skopje.

\section{Sources}

An exhibition about the Skopje earthquake dedicated to the brigadier youth," Sitel television, July 19, 2018, available at https://sitel.com.mk/izlozhbataza-skopskiot-zemjotres-posvetena-na-mladincite-brigadiri

“A new battle for Tito's message," Dneunik daily, October 6, 2010, available at https://daily.mk/what/407955 
On the occasion of the $48^{\text {th }}$ anniversary of the catastrophic earthquake in Skopje on July 26, 1963", the official portal of the city of Skopje, November 27, 2011, available at http://www.skopje.gov.mk/ShowAnnouncements.aspx? ItemID $=4395 \& \mathrm{mid}=482 \&$ tabId $=\&$ tabindex $=0$

"Tito's message removed from the old railway station," skopjeinfo.mk portal, the city alphabet, April 18, 2018, available at https://skopjeinfo.mk/otstraneta-porakata-od-tito-na-starata-zheleznichka-stanica

“Tito's visits to Macedonia," Macedonium, Forum: History, New Century, Macedonia within the Socialist Federative Republic of Yugoslavia, available at http://www.macedonium.org/Macedonium.aspx?jazik=2\&kid=1\&pid=3 \&ppid $=83 \&$ tid $=2221$

"A reminder: who removed Tito's message from the Skopje Museum and how they did it," in "It's very retro, but I like it" (Aj sto mi e retro, em drago), Joci, Virtus Veritas, June 26, 2018, available at http://joci. mk/2018/07/26/\%Do\%BF\%Do\%BE\%D1\%82\%D1\%81\%Do\%B5\%D1\%82\%D1\%83\%Do\%B2\%Do\%Bo\%D1\%9A\%Do\%B5-\%Do\%BA\%D o\%BE\%D1\% 98-\%Do\%B8-\%Do\%BA\%Do\%Bo\%Do\%BA\%Do\%BE\%D1\%98\%Do\%Bo-\%D1\%82\%D1\%80\%Do\%B3\%Do\%BD\%Do\%Bo-\%Do \%BF\%Do\%BE\%D1\%80\%Do\%Bo\%Do\%BA\%Do\%Bo/ and (http://star. vest.com.mk/default.asp?id $=63269 \& i d g=3 \& i d b=896 \&$ rubrika $=$ Skopje)

"Skopje remembers - 50 years since the catastrophic earthquake", Kanal 5 television, June 26, 2013, available at https://www.kanal5.com.mk/articles/179807/skopje-se-sekjava-50-godini-od-katastrofalniot-zemjotres

"Last night a monument of Josip Broz Tito was erected in Skopje," Nova TV, November 29, 2013, available at https://novatv.mk/spomenik-na-josip-broztito-sinokja-e-postaven-vo-skopje/

"Tito's message removed from the museum," Utrinski Vesnik daily, November $8,2010$.

Georgievski, Dzvezdan. "The old railway station, Skopje 1963-2013“, Okno, 22.07.2013, available at https://okno.mk/node/30137

I.P., October 27, 2018, personal FB profile 
Museum of the city of Skopje, history of the museum of Skopje, webpage, available at https://www.mgs.org.mk/index.php/2016-04-06-10-30-16

Museum of the Macedonian Struggle for Statehood and Independence-Museum of the Internal Macedonian Revolutionary Organization and the Museum of the Victims of the Communist Regime, webpage, available at https:// www.mmb.org.mk/index.php/mk, February - March 2019.

Trajkov, Sotir, and Naum Pulendzovski. "Let's restore Tito's message to the wall of the Skopje Museum," Telma television, April 22, 2018, available at https://telma.com.mk/da-se-vrati-porakata-na-tito-na-zidot-na-muzejotna-grad-skopje/

\section{References}

Achkoska, Violeta. 2016 (2011). "The modern Macedonian society between liberalism and re-Bolshevization," Annual omnibus, 87-103. Skopje: Faculty of Philosophy, Department of History and Philology, available at dl.fzf.ukim. edu.mk/index.php/godz/article/download/1147/1126.

Ćalović, Dragan. 2011. "The participation of Yugoslavian post-war art in the consolidation of the image of Josip Broz Tito," Kultura polisa 15(VIII): 177194.

Cipek, Tihomir. 2009. "Remembering 1945: preserving and erasing, on the strength of family narratives, in Culture of remembering: 1945, Historical breaks and tackling the past, 155-165. Zagreb: Dispute.

Gerazova, Iskra. 2006. "He made an uproar again: my personal views of Tito's self," in Tito, the old icon vs. the new contexts, Kula, a Review of the Slovenian Society of Ethnology and Anthropology, special edition, 97-99. Ljubljana.

Jančeva, Ljubica, and Aleksandar Litoski. 2017. "Establishing one's own identity, Macedonia and Macedonians in Yugoslavia," in Yugoslavia from a historical perspective, 149 -171. Helsinki Committee for Human Rights in Serbia.

Kuljić, Todor. 2014. Tanatopolitica, a socio-historical analysis of the political use of death, Žarko Čigoja (ed.). Belgrade: Čigoja. 
Makuljević, Nenad. 2017. "From the art of a nation to the art of a territory, Yugoslavian art and culture," in Yugoslavia from a historical perspective, 414433. Helsinki Committee for Human Rights in Serbia.

Merenik, Lidija. 2009. "The culture of forgetting, Yugoslavian art, and cultural policy cca. 1945 and its fate half a century later seen from the example of the portrait of Josip Broz Tito", in Culture of remembering: 1945, Historical breaks and tackling the past, 127-140. Zagreb: Disput.

Pavićević, Đorđe. 2009. "Communities of remembering and regimes of remembering: towards responsible remembering, in Culture of remembering: 1945, Historical breaks and tackling the past, 93-106. Zagreb: Disput.

Potkonjak, Sanja, and Tomislav Pletenac. 2007. 'City and ideology: "Culture of forgetting" seen from the example of the city of Sisak, Studia ethnologia Croatica 19: 171-198.

Rot, K. 2000. "The national culture of Southeast Europe in the modern age," in Pictures in our heads, reflections on national culture in Southeast Europe, Ivan Čolovič (ed.), 139-160. Belgrade: Biblioteka XX vek.

Velikonja, Mitja. 2008. Titostalgia - A Study of Nostalgia for Josip Broz, Ljubljana: Mirovni Inštitut.

Velikonja, Mitja. 2017. "Yu-rearview mirror was of remembering Yugoslavia", in Yugoslavia from a historical perspective, 485 - 513. Helsinki Committee for Human Rights in Serbia. 
EthnoAnthropoZoom 
EthnoAnthropoZoom 